\title{
Molecular basis for the insulinomimetic effects of C-peptide
}

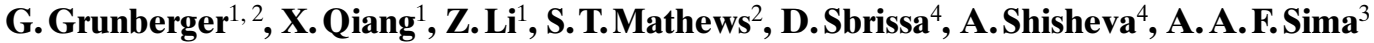 \\ ${ }^{1}$ Centre for Molecular Medicine and Genetics, Wayne State University, Detroit, Mich, USA \\ ${ }^{2}$ Department of Internal Medicine, Wayne State University, Detroit, Michigan, USA \\ ${ }^{3}$ Department of Pathology, Wayne State University, Detroit, Michigan, USA \\ ${ }^{4}$ Department of Physiology, Wayne State University, Detroit, Michigan, USA
}

\section{Abstract}

Aims/hypothesis. C-peptide, released by the betacells of pancreatic islets, elicits salutary responses in Type I (insulin-dependent) diabetes mellitus but the molecular mechanisms behind these effects are not known. We assessed whether synthetic rat C-peptide stimulates insulin-like cellular effects in a classic insulin target tissue.

Methods. To clarify the molecular mechanisms involved in several insulinomimetic actions, we investigated the effect of C-peptide on the insulin signalling pathway in rat skeletal muscle cells. We used L6 myoblasts and myocytes to measure the effects of C-peptide or insulin or both on glycogen synthesis and amino acid uptake. We also studied the effects of C-peptide on insulin receptor autophosphorylation, its tyrosine kinase activity, phosphorylation of IRS-1, PI 3-kinase, Akt, p90Rsk, MAPK, and GSK3 in these cells.

Results. In L6 cells, physiological concentrations of C-peptide (0.3-3 nmol/l) significantly activated insulin receptor tyrosine kinase, IRS-1 tyrosine phospho- rylation, PI 3-kinase activity, MAPK phosphorylation, p90Rsk, and GSK3 phosphorylation. A scrambled C-peptide sequence - the control - showed no effects. Wortmannin blocked C-peptide-induced glycogen synthesis while pertussis toxin had no effect. Only submaximal insulin concentrations (up to 10 nmol/l) combined with submaximal C-peptide concentrations led to additive effects.

Conclusion/interpretation. C-peptide added to the maximal insulin dose $(100 \mathrm{nmol} / \mathrm{l})$ did not increase the effect of insulin alone. We thus conclude that the same signalling elements are used by both ligands. However, the lack of Akt activation by C-peptide and the bell-shaped dose response induced by C-peptide indicate that $\mathrm{C}$-peptide has some effects by another distinct mechanism. We speculate that C-peptide could modulate the metabolic effects of insulin by enhancing them at low hormone concentrations and dampening them at high hormone concentrations. [Diabetologia (2001) 44: 1247-1257]

Keywords C-Peptide signalling, signal transduction, L6 myoblasts/myotubes, insulin action.
Received: 19 December 2000 and in revised form: 11 June 2001

Corresponding author: G. Grunberger, Department of Internal Medicine Wayne State University, Health Center-4H, 4201 St. Antoine, Detroit, MI 48201, USA

e-mail: g.grunberger@wayne.edu

Abbreviations: PI3 K, Phosphatidylinositol 3-kinase; MAPK, mitogen-activated protein kinase; Rsk, ribosomal S6 kinase; IR, insulin receptor; TKA, tyrosine kinase activity; FCS, fluorescent correlation spectroscopy; IRS-1, insulin receptor substrate-1
C-peptide is a 31-amino acid peptide that is derived from proinsulin during biosynthesis of insulin [1]. Beneficial effects of C-peptide replacement, along with insulin, in C-peptide deficient states have been documented [2-5]. In patients with Type I (insulindependent) diabetes mellitus, C-peptide improves renal function, reduces urinary albumin excretion and glomerular filtration and blood retinal barrier leakage [4]. It also ameliorates nerve dysfunction [5]. Heart rate variability during deep breathing increases and sensory nerve function improves in Type I diabetic patients after a 3-h and a 3-month administra- 
tion of C-peptide. We show that chronic C-peptide replacement prevents both the acute and chronic metabolic, functional and structural changes in the Type I diabetic $B B /$ Wor rat model [6].

In spite of the above mentioned data the very existence of biological effects of C-peptide has been questioned and the molecular mechanisms behind these therapeutic effects are not known. No specific C-peptide receptor has been identified [7]. The introduction of a sensitive method, fluorescent correlation spectroscopy (FCS), has allowed specific C-peptide binding to human cells to be detected but the structure of the receptor is still not known. The C-terminal pentapeptide seems to be responsible for the specific binding to the receptor [8]. Pretreatment of cells with pertussis toxin abolishes specific C-peptide binding [8]. This observation, along with inhibition of several C-peptide effects by pertussis toxin, indicates that C-peptide binds to a G-protein coupled receptor $[2,8]$. Human C-peptide stimulates glucose transport in human non-diabetic and diabetic skeletal muscle $[9,10]$. Pending purification and cloning of the C-peptide receptor, we explored the details of C-peptide signal transduction in an insulin-responsive system.

The physiologic effects of insulin stem from insulin binding to the extracellular domain of the insulin receptor (IR) [11]. Binding results in activation of the IR tyrosine kinase (TKA), followed by the phosphorylation of intracellular substrates, propagating receptor signals throughout the cell. These include the Ras/mitogen-activated protein kinase (MAPK) cascade and the phosphatidylinositol 3-kinase (PI3 K)/ Akt (protein kinase B, PKB) system, thought to play key roles in the mitogenic and metabolic arms of insulin signalling, respectively $[12,13]$. We have previously shown that C-peptide, enhanced insulin-stimulated IR autophosphorylation and TKA in vitro, suggesting that C-peptide affects other downstream elements of insulin signal transduction pathways.

\section{Materials and methods}

Materials. Synthetic rat-II C-peptide with greater than $98 \%$ purity (by HPLC, Genosys, Cambridge, UK) and scrambled C-peptide were provided by J. Wahren (Karolinska Institutet, Stockholm, Sweden). The L6 cells and 3T3-L1 fibroblasts were purchased from American Type Culture Collection (Rockville, Md., USA). Culture reagents, including Dulbecco's modified Eagle's medium (DMEM), fetal bovine and horse serum, trypsin, and penicillin/streptomycin were obtained from Life Technologies (Grand Island, NY, USA). Chemicals were purchased from Fisher Scientific (Itasca, Ill., USA), Sigma Chemical (St. Louis, Mo., USA), and Bio-Rad Laboratories (Hercules, Calif., USA). Phospho-Akt (Thr308) antibody, phospho-p44/42 MAP kinase (Thr202/Tyr204) antibody, phospho-p90Rsk (Ser381) antibody, and phospho-GSK$3 \alpha / \beta$ (Ser21/9) antibody were from New England Biolabs (Beverly, Mass., USA), anti-Akt 1 antibody was from Santa Cruz Biotechnology (Santa Cruz, Calif., USA), anti-IRS-1 an- tibody and anti-phosphotyrosine antibody were from Transduction Laboratories (Lexington, Ky., USA) and anti-insulin receptor B-subunit antibody was from Sigma. HRP-conjugated secondary antibodies were from Kirkegaard and Perry (Gaithersburg, Md., USA), ECL reagents were purchased from Pierce (Rockford, Ill., USA). The $\mathrm{D}-\left[{ }^{14} \mathrm{C}\right]$-glucose, $\left[{ }^{14} \mathrm{C}\right]-$ methylaminoisobutyric acid and $\left[\left(\gamma-{ }^{32} \mathrm{P}\right]\right.$-ATP, ${ }^{32} \mathrm{P}$-orthophosphoric acid were purchased from NEN Life Science Products (Boston, Mass., USA).

Cell culture. The L6 rat skeletal myoblasts were maintained in DMEM containing 20\% (v/v) fetal bovine serum, 100 units/ $\mathrm{ml}$ penicillin/streptomycin and $2 \mathrm{mmol} / 1$ glutamine at $37^{\circ} \mathrm{C}$ in a humidified atmosphere with $5 \%(\mathrm{v} / \mathrm{v}) \mathrm{CO}_{2}$. Cells at $90 \%$ confluence were used in all experiments. Myoblasts were induced to form myotubes by incubation for up to 5-6 days in DMEM containing $2 \%(\mathrm{v} / \mathrm{v})$ horse serum, $100 \mathrm{units} / \mathrm{ml}$ penicillin/streptomycin and $2 \mathrm{mmol} / \mathrm{l}$ glutamine. Parental 3T3-L1 preadipocytes were differentiated into adipocytes as described earlier [15].

Insulin receptor purification and tyrosine kinase assay. "Receptors" were partially purified from L6 membranes from 12 dishes $(10 \mathrm{~cm})$ by wheat germ agglutinin chromatography. This process results in about a 25 -fold enrichment in the preparation's content of insulin receptors. However, other membrane glycoproteins were also present. The TKA of this preparation was assayed by detection of phosphorylation of a synthetic substrate poly $\left(\mathrm{Glu}^{4} \mathrm{Tyr}^{1}\right)$ in the presence of $\left[\gamma_{-}{ }^{32} \mathrm{P}\right]-\mathrm{ATP}[16]$. Aliquots of these receptors were incubated for $20 \mathrm{~min}$ at room temperature in the absence or presence of insulin (10, $100 \mathrm{nmol} / \mathrm{l})$ or C-peptide or both $(0.1,0.3,1,3,10,30,100$ and $1000 \mathrm{nmol} / \mathrm{l})$. L6 myotube lysates were immunoprecipitated with anti-IR antibody and immunocomplexes were captured with protein G/protein A-agarose. The TKA of this preparation was assayed as described above.

Glycogen synthesis. Monolayers of confluent L6 myoblast cells were serum-starved for $16 \mathrm{~h}$ and incubated for $3 \mathrm{~h}$ in DMEM containing $2.5 \mathrm{mmol} / \mathrm{l}$ glucose, $0.1 \% \mathrm{BSA}$ and $25 \mathrm{mmol} / \mathrm{l} \mathrm{HE}$ PES, $\mathrm{pH}$ 7.4. They were stimulated with the hormones for $1 \mathrm{~h}$ at $37^{\circ} \mathrm{C}$ and then incubated with [U- $\left.{ }^{14} \mathrm{C}\right]-\mathrm{D}-$ glucose for $90 \mathrm{~min}$. In some experiments, cells were treated with wortmannin $(100 \mathrm{nmol} / \mathrm{l})$ for $30 \mathrm{~min} \mathrm{[17]} \mathrm{or} \mathrm{with} \mathrm{pertussis} \mathrm{toxin,} 1 \mu \mathrm{g} / \mathrm{ml}$

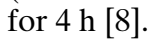

$\left[{ }^{14} \mathrm{C}\right]$-Aminoisobutyric acid uptake. Monolayers of confluent L6 myoblast cells were serum-starved for $16 \mathrm{~h}$ and stimulated with insulin or C-peptide or both for $1 \mathrm{~h}$ at $37^{\circ} \mathrm{C}$ and incubated with $\left[{ }^{14} \mathrm{C}\right]$-aminoisobutyric acid for $30 \mathrm{~min}$. Amino acid uptake was measured as previously described [18].

PI 3-kinase activity. The PI3 $\mathrm{K}$ activity associated with phosphotyrosine immune complexes derived from L6 myoblasts and 3T3-L1 adipocytes was measured as reported earlier [19].

Western blotting and immunoprecipitation. Confluent monolayers of L6 cells or 3T3-L1 adipocytes were serum-starved for $16 \mathrm{~h}$ and stimulated with the hormones for $10 \mathrm{~min}$. Cells were lysed at $4{ }^{\circ} \mathrm{C}$ with ice-cold lysis buffer containing $20 \mathrm{mmol} / \mathrm{l}$ HEPES, pH 7.4, $1 \mathrm{mmol} / \mathrm{l} \mathrm{Na}_{3} \mathrm{VO}_{4}, 5 \mathrm{mmol} / \mathrm{l}$ EDTA, $100 \mathrm{mmol} / \mathrm{l} \mathrm{NaF}, 20 \mathrm{mmol} / 1 \mathrm{Na}_{4} \mathrm{P}_{2} \mathrm{O}_{7}, 1 \mathrm{mmol} / \mathrm{l} \mathrm{PMSF}$, $10 \mu \mathrm{g} / \mathrm{ml}$ of aprotinin, leupeptin and benzamidine, $50 \mu \mathrm{g} / \mathrm{ml}$ soybean trypsin inhibitor, and $1 \%$ Triton X-100. Lysates were clarified by centrifugation at $12000 \mathrm{~g}$ for $15 \mathrm{~min}$ at $4{ }^{\circ} \mathrm{C}$ and the supernatants were collected, separated by $7.5 \%$ SDS-polyacrylamide gel electrophoresis, transferred to nitrocellulose- 
membranes, and immunoblotted with the appropriate primary antibody (phospho-Akt, phospho-MAP kinase, phospho-Rsk, phospho-GSK3). Specific proteins were visualized with chemiluminescence (ECL). To study phosphorylation of Akt directly, L6 myoblasts were serum-starved in phosphate-free DMEM for $16 \mathrm{~h}$, pre-incubated with ${ }^{32} \mathrm{P}$-orthophosphoric acid for $6 \mathrm{~h}$ and stimulated with C-peptide or insulin or both. Lysates were immunoprecipitated with anti-Akt 1 antibody, captured with protein $\mathrm{G} /$ protein A-agarose and subjected to $7.5 \%$ SDS-PAGE. This was followed by autoradiography [20]. To study phosphorylation of IR and IRS-1, lysates were immunoprecipitated with anti-IR antibody or anti-IRS-1 antibody. The immunocomplexes were captured with protein $\mathrm{G} /$ protein A-agarose and subjected to SDS-PAGE and immunoblotting with anti-phosphotyrosine antibody as described earlier [21]. Quantitation of data was done by UN-SCAN-IT GEL Automated Digitizing System (Silk Scientific, Orem, Utah., USA).

RSK kinase assay in L6 myoblasts. L6 lysates were used for immunoprecipitation with anti-Rsk-1 antibody. The immunocomplexes were captured with protein $\mathrm{A} / \mathrm{G}$-agarose as described above. Kinase reaction was initiated by the addition of a S6 substrate (RRRLSRA) mixture containing $25 \mu \mathrm{mol} / 1$ cold ATP, $0.1 \mu \mathrm{Ci}\left[\gamma_{-}{ }^{32} \mathrm{P}\right] \mathrm{ATP}$, and stopped by spotting $50 \mu \mathrm{l}$ of the kinase reaction onto phosphocellulose paper (Whatman $\mathrm{P}-81$ ). Incorporated radioactivity was measured by liquid scintillation counting in a beta counter [22].

Statistical analysis. Student's $t$ test or analysis of variance (ANOVA) was used for statistical analysis of data. Results are expressed as Means \pm SEM. A $p$ value of less than 0.05 was considered statistically significant.

\section{Results}

Effect of C-peptide on glycogen synthesis. Pre-incubation with rat-II C-peptide led to a 2.5 -fold increase in glycogen synthesis in L6 rat myoblasts. The dose-dependent effect of C-peptide showed a bell-shaped curve (Fig. 1A). Statistically significant stimulation started at $0.3 \mathrm{nmol} / \mathrm{l}$ and maximum effect was observed between 1 and $3 \mathrm{nmol} / \mathrm{l}$ of $\mathrm{C}$-peptide. It required $10 \mathrm{nmol} / \mathrm{l}$ of insulin to achieve the twofold stimulation seen with $0.3 \mathrm{nmol} / \mathrm{l}$ of $\mathrm{C}$-peptide. Maximum effect of insulin (fourfold stimulation of glycogen synthesis) was observed with $100 \mathrm{nmol} / \mathrm{l}$. Higher insulin concentrations (up to $10 \mu \mathrm{mol} / \mathrm{l}$ ) increased glycogen synthesis to the same degree as $100 \mathrm{nmol} / \mathrm{l}$. Scrambled C-peptide sequence (random arrangement of the 31 amino acids of $\mathrm{C}$-peptide), serving as a control ( 1 and $3 \mathrm{nmol} / \mathrm{l}$ concentrations depicted in Fig.1A), did not increase glycogen synthesis above basal values. Human C-peptide increased glycogen synthesis to the same degree as the homologous (rat) C-peptide (not shown). The interactive effects of insulin and C-peptide were also examined. Combinations of submaximally effective insulin $(10 \mathrm{nmol} / \mathrm{l})$ and submaximal concentrations of C-peptide $(0.1$ and $0.3 \mathrm{nmol} / \mathrm{l})$ led to increased glycogen synthesis more than either ligand alone (Fig.1B). Combina-

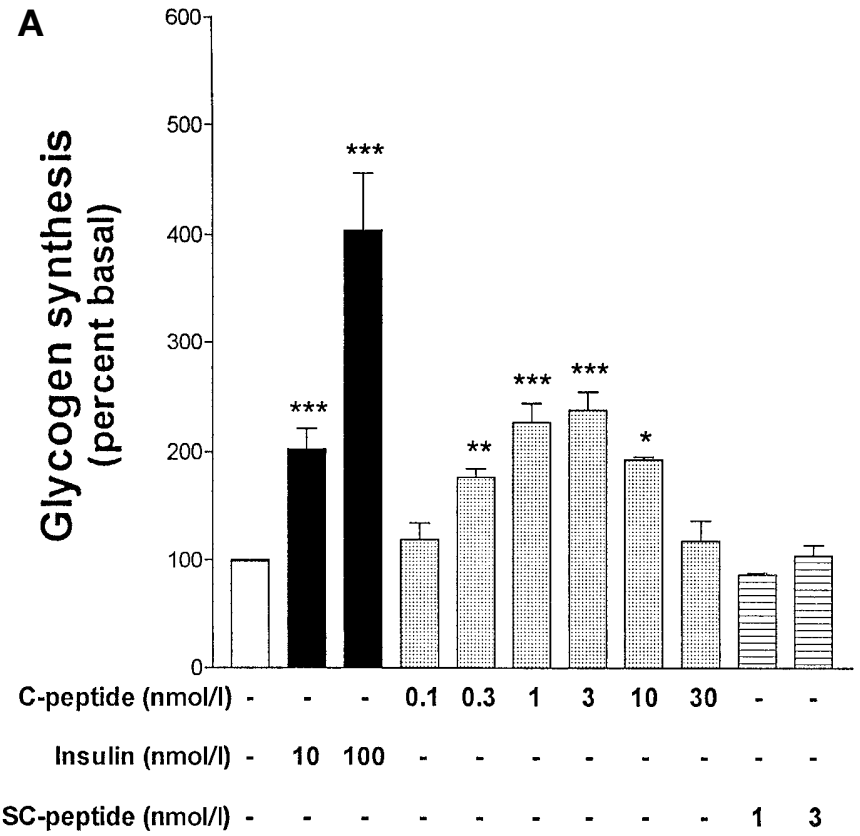

B

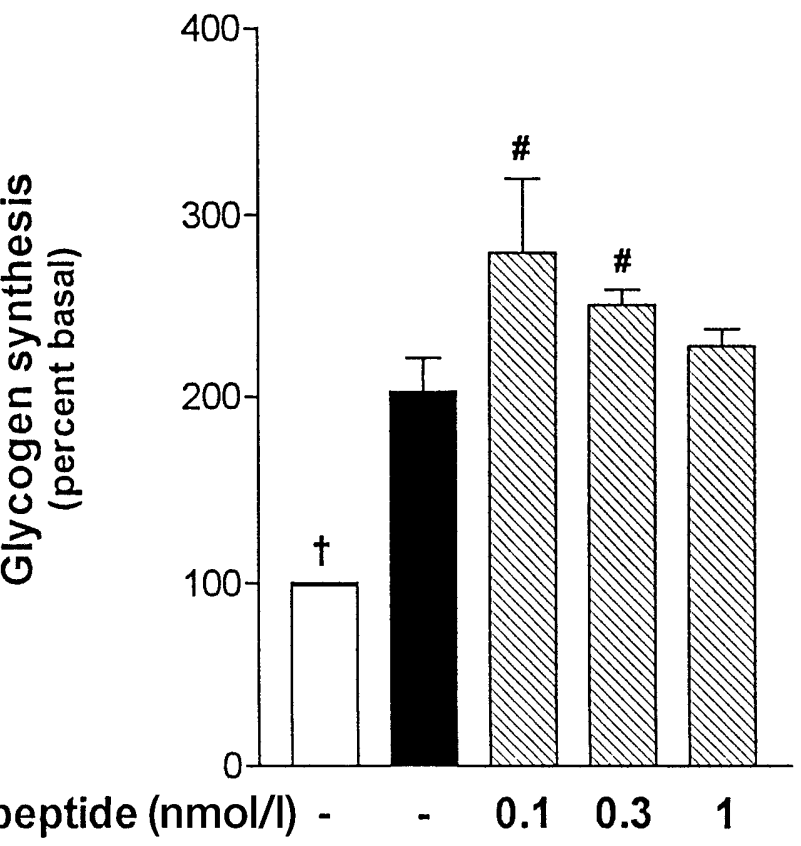

Insulin (nmol/l) - $\begin{array}{llll}10 & 10 & 10 & 10\end{array}$

Fig.1 (A, B). C-peptide stimulates glycogen synthesis in L6 myoblasts. Monolayers of confluent L6 myoblast cells were serum-starved for $16 \mathrm{~h}$ and stimulated with insulin, Cpeptide, and scrambled C-peptide for $1 \mathrm{~h}(\mathbf{A})$ or with a combination of insulin and C-peptide $[(\mathbf{B})$ where the results with 10 $\mathrm{nmol} / \mathrm{l}$ insulin are shown for comparison]. Glycogen synthesis was assessed by measuring $\mathrm{D}-\left[{ }^{14} \mathrm{C}\right]$-glucose incorporation into glycogen. Results are plotted as Means \pm SEM of ten separate experiments (each in quadruplicate) and normalized with respect to control $(=100 \%)$. $* * * p<0.001, * * p<0.01, * p<0.05$ vs control (A), and ${ }^{\dagger} p<0.05$ vs every sample, $\# p<0.05$ vs insulin, $10 \mathrm{nmol} / \mathrm{l}(\mathbf{B})$ 
Fig. 2 (A, B). C-peptide stimulates $\left[{ }^{14} \mathrm{C}\right]$-aminoisobutyric acid uptake in L6 myoblasts. Monolayers of confluent L6 myoblast cells were serum-starved for $16 \mathrm{~h}$ and then incubated with insulin, C-peptide, or a scrambled C-peptide sequence (SC-peptide) (A) or with a combination of insulin and C-peptide (B, where results with $10 \mathrm{nmol} / \mathrm{l}$ insulin are shown for comparison) for $1 \mathrm{~h}$. Amino acid uptake was measured by $\left[{ }^{14} \mathrm{C}\right]-$ methylaminoisobutyric acid incorporation. Results are shown as Means \pm SEM of three separate experiments. $* * * p<0.001$, ${ }^{* *} p<0.01, * p<0.05$ vs control (A), and ${ }^{\dagger} p<0.05$ vs every sample, $\# p<0.05$ vs insulin, $10 \mathrm{nmol} / 1$ (B)

tions of maximally effective concentrations of insulin and C-peptide, however, did not increase glycogen synthesis more than either ligand alone.

Effect of C-peptide on amino acid uptake. We next measured aminoisobutyric uptake, as another example of biologic effect of insulin in L6 cells. C-peptide (1-10 nmol/l) stimulated amino acid uptake more than twofold in L6 myoblasts, an effect similar to that of $10 \mathrm{nmol} / \mathrm{l}$ of insulin (Fig. 2A). Statistically significant stimulation was documented between $0.3 \mathrm{nmol} / 1$ and $10 \mathrm{nmol} / \mathrm{l}$ of C-peptide. Scrambled C-peptide (up to $3 \mathrm{nmol} / \mathrm{l}$ ) did not increase the aminoisobutyric acid uptake over baseline. Addition of C-peptide (0.1-1 $\mathrm{nmol} / \mathrm{l})$ to the submaximally effective insulin concentration $(10 \mathrm{nmol} / \mathrm{l})$ significantly increased the amino acid uptake achieved with insulin alone (Fig. 2B).

Effect of C-peptide on GSK3 phosphorylation. We studied the molecular basis for the insulinomimetic effect of C-peptide on glycogen synthesis. Evidence indicates that insulin stimulates glycogen synthase by both activating protein phosphatase 1 and by inhibiting GSK3, which is inactivated by phosphorylation [17]. Insulin $(10,100 \mathrm{nmol} / \mathrm{l})$ increased GSK3 phosphorylation in L6 myoblasts (over fivefold and 12-fold, respectively). C-peptide pre-incubation of the cells, with physiological concentrations (0.3-3 nmol/l) increased GSK3 phosphorylation (7.5-fold and five-fold, respectively) (Fig.3A). As in the other assays, the highest C-peptide concentration (30 nmol/l) had no effect on GSK3 phosphorylation. Scrambled C-peptide $(0.3$ and $3 \mathrm{nmol} / \mathrm{l})$, used as a control, also had no effect on GSK3 phosphorylation. The combinations of $10 \mathrm{nmol} / \mathrm{l}$ insulin with either 0.1 or $0.3 \mathrm{nmol} / \mathrm{l} \mathrm{C}$-peptide showed a slight but statistically significant increase in GSK3 phosphorylation that was greater than the effect of either hormone alone (Fig. 3B and C). C-peptide could therefore stimulate glycogen synthesis by inhibiting GSK3. Because modulation of GSK3 is clearly not the only mechanism by which glycogen synthesis is stimulated, a precise quantitative correspondence between the results from the glycogen synthesis and GSK3 assays cannot be expected.
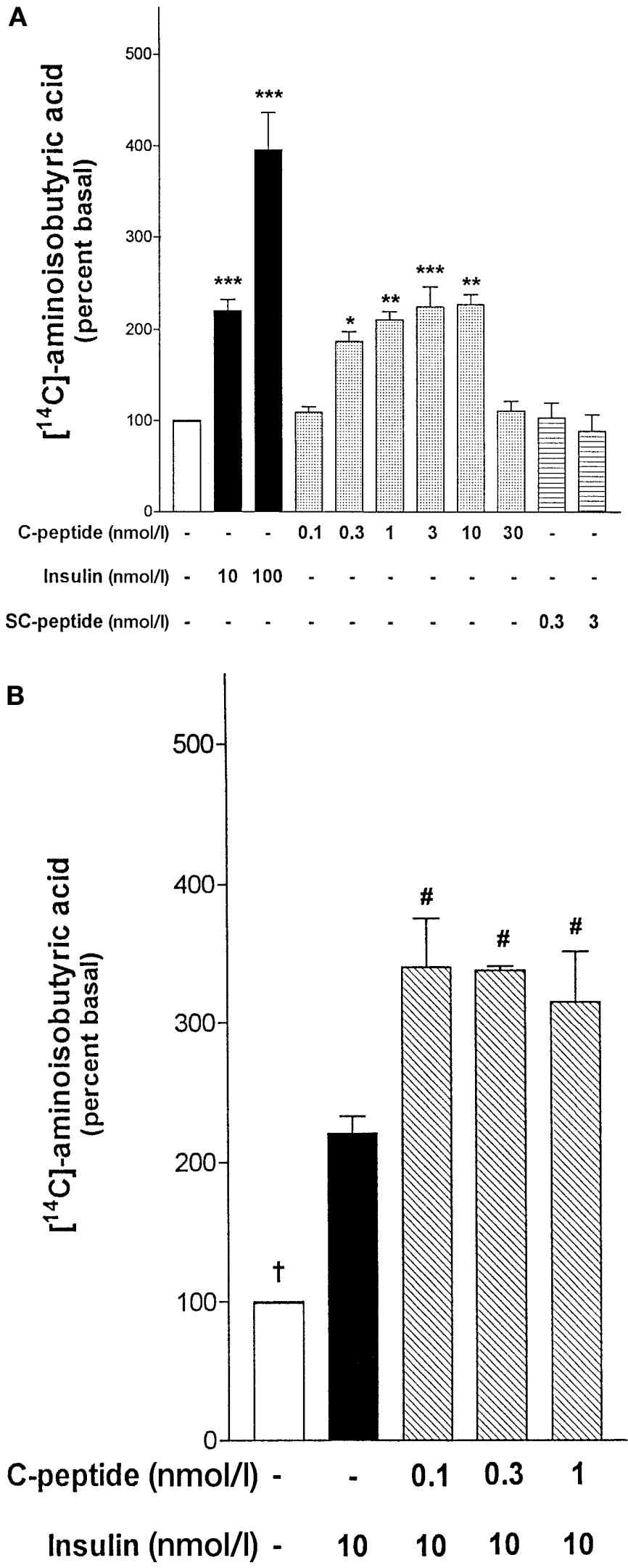


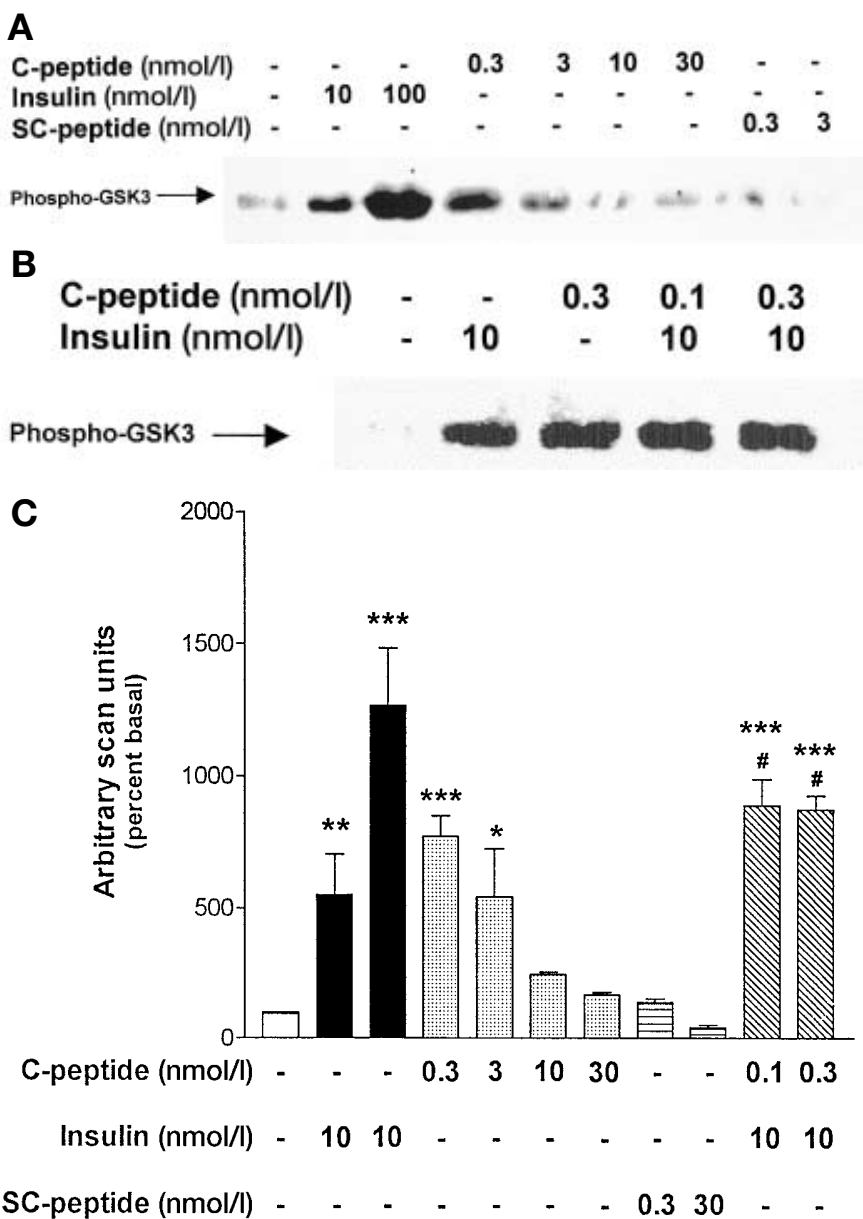

Fig. 3 (A-C). C-peptide stimulates GSK3 phosphorylation. Serum-starved confluent L6 myoblasts were incubated with insulin, C-peptide and scrambled C-peptide (A), and a combination of insulin with C-peptide (B) for $10 \mathrm{~min}$. Cell lysates were separated on $7.5 \%$ SDS-PAGE, transferred to nitrocellulose membrane and immunoblotted with anti-phospho-GSK3 antibody (four separate experiments). The phosphorylated GSK3 is shown in this representative blot as a band of about $47 \mathrm{kD}$ (arrow). C: Quantitation of data (four separate experiments) is depicted as Means \pm SEM for each condition normalized for control $(=100 \%)$. $* * * p<0.001, * * p<0.01, * p<0.05$ vs control, and $\# p<0.05$ vs insulin, $10 \mathrm{nmol} / 1$

Effect of C-peptide on Akt phosphorylation in L6 cells. Insulin (more than fivefold) activates phosphorylation of Akt in L6 cells greatly (Fig. 4). In spite of the expectations raised by the insulinomimetic effects of C-peptide on glycogen synthesis, amino acid uptake and GSK3 phosphorylation, C-peptide (at concentrations of up to $30 \mathrm{nmol} / \mathrm{l}$ ) did not stimulate phosphorylation of Akt, as assessed by immunoprecipitating or by immunoblotting with an anti-phospho Akt antibody (Thr-308). Furthermore, in a separate study, intact L6 myotubes were labelled with ${ }^{32} \mathrm{P}$-orthophosphoric acid for $6 \mathrm{~h}$ and stimulated with insulin, with C-peptide $(0.3,3 \mathrm{nmol} / \mathrm{l})$, with scrambled C-peptide $(0.3 \mathrm{nmol} / \mathrm{l})$, or a combination of insulin and C-peptide. Cell lysates were immunoprecipitated with anti-

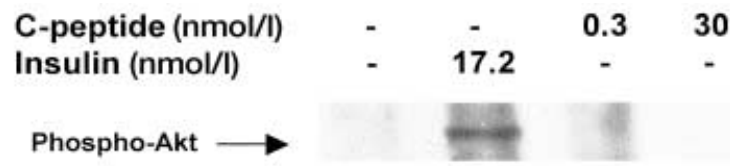

Fig. 4. C-peptide does not activate Akt. Serum-starved confluent L6 myotubes were incubated with insulin $(17.2 \mathrm{nmol} / \mathrm{l})$, and with C-peptide $(0.3,30 \mathrm{nmol} / \mathrm{l})$. Cell lysates were separated on $10 \%$ SDS-PAGE, transferred to nitrocellulose membrane and immunoblotted with anti-phospho Akt antibody. A representative blot (out of three separate experiments) shows that insulin did (12.6-fold) but C-peptide did not stimulate phosphorylation of Akt (arrow)

Akt 1 antibody, captured with protein G/protein A-agarose, and separated on $7.5 \%$ SDS-PAGE. While insulin $(10 \mathrm{nmol} / \mathrm{l})$ stimulated phosphorylation of Akt 3.1-fold, no increase of Akt phosphorylation was seen in cells pre-incubated with either C-peptide or with the scrambled C-peptide sequence (not shown). The combination of insulin and C-peptide yielded the same effect as that seen with insulin alone (2.9-fold increase in Akt phosphorylation).

In summary, the Akt phosphorylation experiments were done with three different cell types (L6 myoblasts, L6 myotubes, and HIRcB cells which are rat fibroblasts overexpressing the human insulin receptors), using two different antibodies (anti-phospho Akt which was directed at both Akt 1 and Akt 2 isoforms and anti-Akt 1 antibody), and different methodologies (immunoprecipitation, immunoblotting, ${ }^{32} \mathrm{P}$ labelling). C-peptide did not increase Akt activation in any of these experiments indicating that the observed insulinomimetic biological effects of C-peptide (Fig. 1 and 2) probably involve divergent signalling pathways proximal to Akt.

Effect of C-peptide on Rsk phosphorylation. We next examined the effect of C-peptide on another signalling step proximal to metabolic effects, i. e. phosphorylation of Rsk. As expected, insulin increased Rsk phosphorylation in L6 myoblasts (3.8-fold increase with $10 \mathrm{nmol} / 1$ insulin) (Fig. 5A) and in L6 myotubes (not shown). Incubation with C-peptide, with concentrations as low as $0.3 \mathrm{nmol} / \mathrm{l}$ also stimulated Rsk phosphorylation (2.6-fold). In contrast, scrambled C-peptide (up to $30 \mathrm{nmol} / \mathrm{l}$ ) had no effect on Rsk phosphorylation. We also assessed activation of Rsk by assessing its enzyme activity, using the p70S6 Rsk substrate (RRRLSSLRA). C-peptide, at 0.3 and $3 \mathrm{nmol} / 1$, led to similar Rsk activation as did insulin (10 and 100 nmol/1) in L6 myoblasts (Fig. 5B). Results from these two different assays can only be compared qualitatively because different methodologies were used. The effect on the overall phosphorylation status of p90Rsk was assessed (Fig. 5A). Phosphorylation of a generic Rsk fragment as a substrate was measured (Fig. 5B). Combination of submaximally effective insulin concentration $(10 \mathrm{nmol} / \mathrm{l})$ and C-peptide (0.1 
A

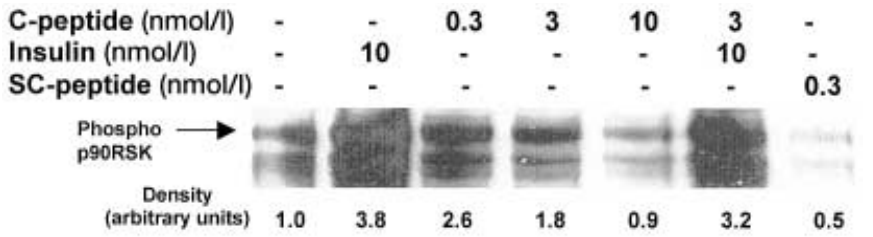

B

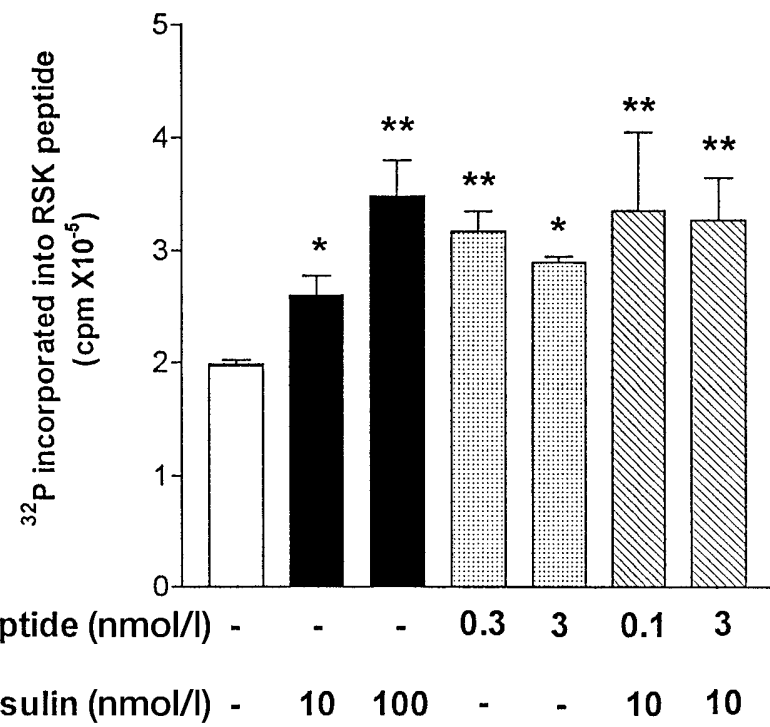

Fig. 5 (A, B). C-peptide activates p90Rsk in L6 myoblasts. Serum-starved confluent monolayers of L6 myoblasts were incubated with $10 \mathrm{nmol} / \mathrm{l}$ insulin, with C-peptide $(0.3,3$ and 10 $\mathrm{nmol} / \mathrm{l})$, or with scrambled C-peptide $(0.3 \mathrm{nmol} / \mathrm{l})$. Cell lysates were separated on Ready gel, transferred to nitrocellulose membrane and immunoblotted with anti-phospho-p90Rsk antibody (A) Arrow indicates the position of phosphorylated p90Rsk. Arbitrary density units (control =1.0) are shown for each condition. Rsk activity was also assessed using p70S6 Rsk substrate (RRRLSSLRA) as described in Methods (B). Results are expressed as Means \pm SEM of three experiments. $* * p<0.01, * p<0.05$ vs. control

and $3 \mathrm{nmol} / \mathrm{l}$ ) increased the Rsk activity slightly more than that achieved with $10 \mathrm{nmol} / \mathrm{l}$ insulin alone.

Effect of C-peptide on MAPK phosphorylation. Biological actions of insulin in skeletal muscle are mediated by a complex interplay of multiple signalling cascades [13]. One of these insulin-activated signalling pathways involves the stimulation of phosphorylation and activation of MAPK or extracellular regulated kinase (ERK). Our results show that both insulin (10 and $100 \mathrm{nmol} / \mathrm{l}$ ) and C-peptide (between 0.3 and 10 nmol/l) increased phosphorylation of MAPK in L6 myoblasts (Fig. 6A and B). To confirm that these observations were not limited to L6 cells, we also assessed MAPK activation in differentiated 3T3-L1 adipocytes (Fig. 6C). Incubations with either insulin or C-peptide did not significantly alter ERK protein expression in those cells (not shown). When the results are expressed as phosphorylated MAPK/ERK2 ratio, in 3T3-L1 adipocytes, pre-incubation with insulin led
A

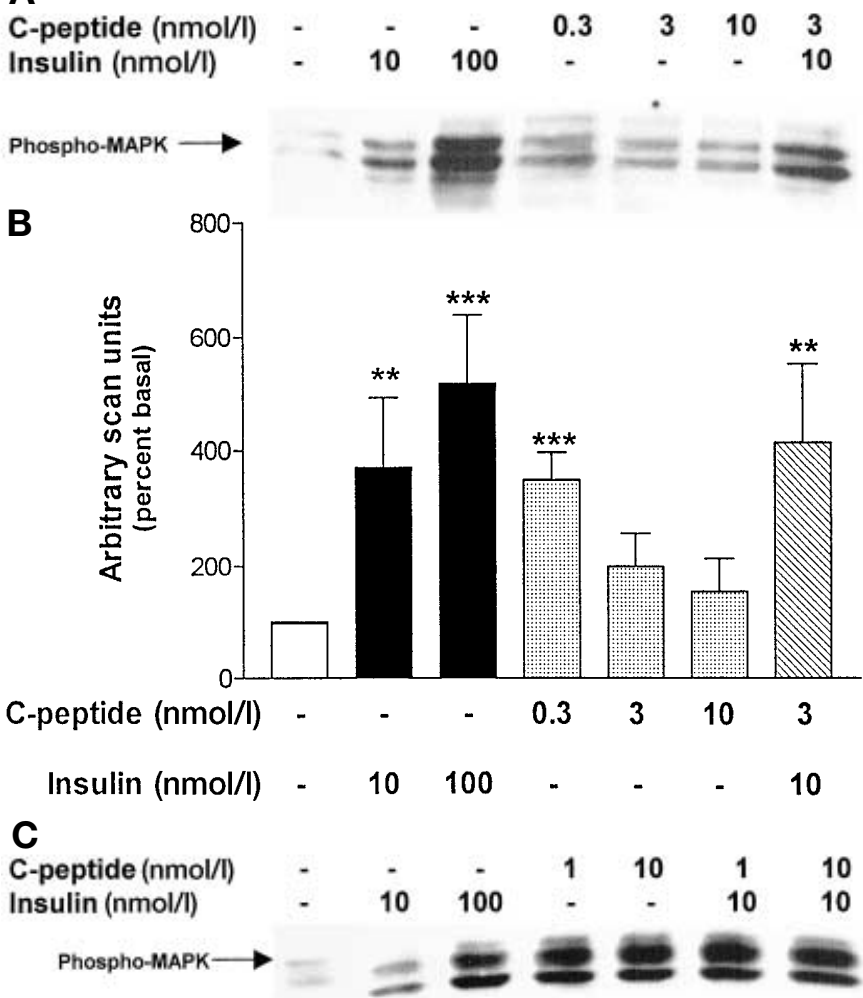

Fig.6 (A-C). C-peptide stimulates MAPK activation in L6 myoblasts and 3T3-L1 fibroblasts. L6 myoblasts (A) or 3T3-L1 cells $(\mathbf{C})$ were incubated with various concentrations of insulin, C-peptide and a combination of insulin with C-peptide for 10 min. Cell lysates were separated on Ready gel, transferred to nitrocellulose membrane and immunoblotted anti-phospho-MAPK antibody (phospho-MAPK indicated by arrow). Quantitation of data (four separate experiments in L6 myoblasts) is shown as Means \pm SEM for each condition normalized for control $(=100 \%) ; * * p<0.001,{ }^{* *} p<0.01$, $* p<0.05$ vs control $(\mathbf{B})$

to a 4-fold to 8-fold increase, while incubation with C-peptide led to a 1.5-fold to 4-fold increase in L6 myoblasts and 3T3-L1 adipocytes.

Effect of C-peptide on PI 3-kinase activity. To assess the potential role of PI3Ks in C-peptide stimulation of glycogen synthesis in L6 myoblasts, we examined glycogen synthesis in the presence of a PI3 K inhibitor. Wortmannin $(100 \mathrm{nmol} / \mathrm{l})$ completely abolished the C-peptide-, insulin- as well as the combination of C-peptide/insulin-stimulated glycogen synthesis (Fig.7) indicating the involvement of wortmanninsensitive class $1 \mathrm{~A}$ or $3 \mathrm{PI} 3 \mathrm{Ks}$ in the C-peptide-stimulated glycogen synthesis [23]. Direct demonstration of the effect of C-peptide on class $1 \mathrm{~A}$ PI3 K activity is seen in Figure 8. In an insulin-responsive, differentiated 3T3-L1 adipocyte system used as a control system, insulin stimulated the PI3 K activity associated with tyrosine-phosphorylated proteins (approximately a 5-fold stimulation at $100 \mathrm{nmol} / \mathrm{l})$. C-peptide (100 


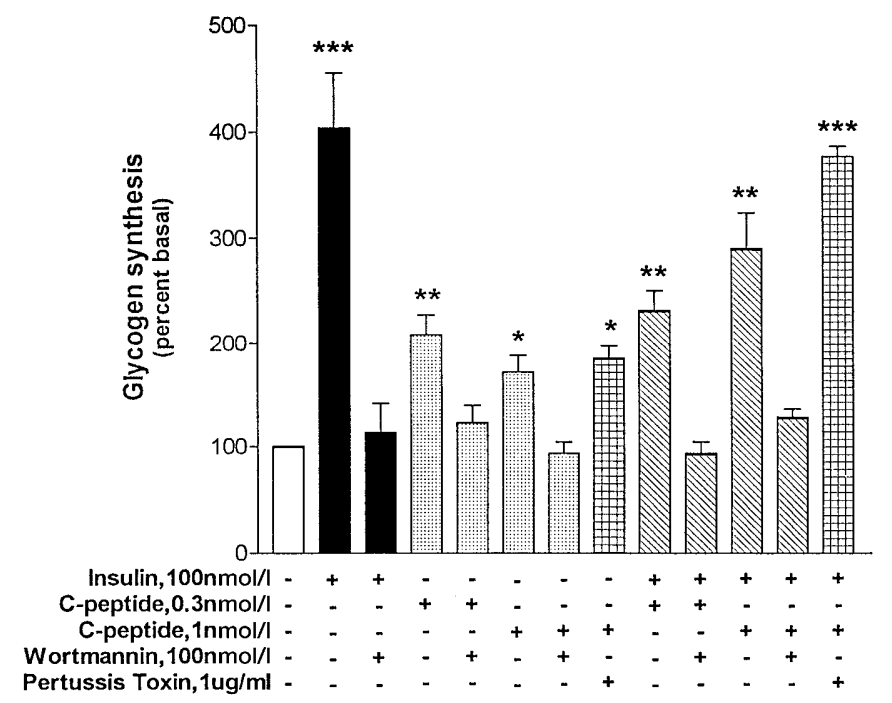

Fig.7. C-peptide-stimulated glycogen synthesis in L6 myoblasts is wortmannin sensitive but pertussis toxin independent. Monolayers of confluent L6 myoblast cells were serum-starved for $16 \mathrm{~h}$ and pretreated with either wortmannin $(100 \mathrm{nmol} / \mathrm{l})$ for $30 \mathrm{~min}$ or with pertussis toxin $(1 \mu \mathrm{g} / \mathrm{ml})$ for $4 \mathrm{~h}$ and then incubated with insulin $(100 \mathrm{nmol} / \mathrm{l})$, with C-peptide $(0.3 \mathrm{nmol} / \mathrm{l})$, or with insulin and C-peptide combinations for $1 \mathrm{~h}$. Glycogen synthesis was assessed by measuring $\mathrm{D}-\left[{ }^{14} \mathrm{C}\right]$-glucose incorporation into glycogen. Results are plotted as Means \pm SEM of four separate experiments (each in quadruplicate) and normalized with respect to control $(=100 \%)$. ${ }^{* * *} p<0.001$, ${ }^{* *} p<0.01$, $* p<0.05$ vs control

nmol/1) also increased (approximately 2-fold) PI3 K activity in these anti-phosphotyrosine immunoprecipitates. Pre-incubation of adipocytes with EGF had no effect on PI3 K activity (Fig. 8A). In a separate experiment shown in Figure 8B, C-peptide at concentrations of 1,10 , and $100 \mathrm{nmol} / \mathrm{l}$ increased PI3 $\mathrm{K}$ activity in a dose-dependent manner. When the assays were done in the presence of wortmannin, PI3 K activity was completely abolished (Fig. 8B). The combination of submaximal concentrations of C-peptide $(0.5 \mathrm{nmol} / \mathrm{l})$ with submaximal insulin $(1$ and $10 \mathrm{nmol} / \mathrm{l})$ increased PI3 K activity by $54 \%$ and $19 \%$, respectively, above that seen with insulin $(10 \mathrm{nmol} / \mathrm{l})$ alone (not shown). To measure the C-peptide effect, experiments were done in L6 myoblasts using the maximally effective concentrations $(100 \mathrm{nmol} / \mathrm{l})$ of insulin and C-peptide. We found that C-peptide increased the activation of PI3 K by about $60 \%$ (Fig. $8 \mathrm{C}$ and D) but our assay only assessed the activity of that small portion of PI3 K that associates with anti-phosphotyrosine immunoprecipitates (about $1-4 \%$ of the total PI3 K activity).

Effect of C-peptide on IRS-1 phosphorylation. To study the upstream mediator of C-peptide-induced PI3 K activation, we examined the effect of C-peptide on IRS-1 tyrosine phosphorylation. We treated L6 myoblasts with C-peptide $(0.3$ and $3 \mathrm{nmol} / \mathrm{l})$ or in-
A

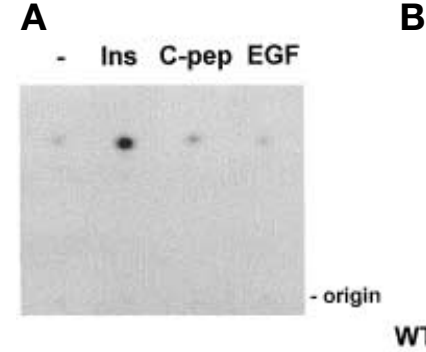

B C-peptide $(\mathrm{nmol} / \mathrm{l})$
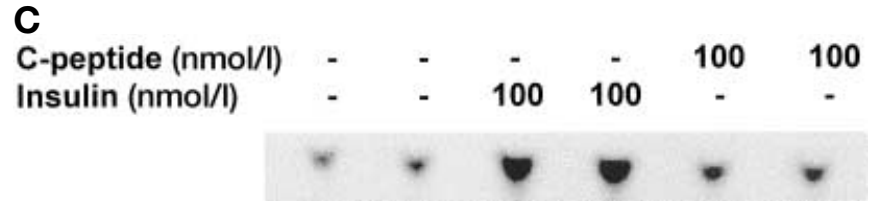

D
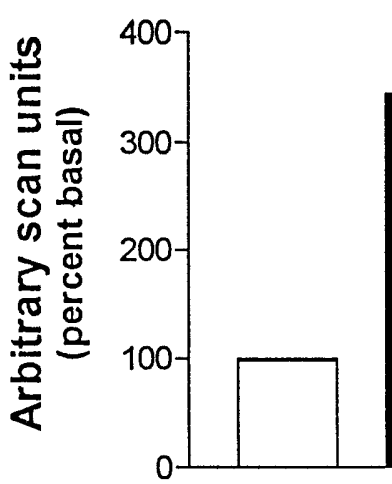

C-peptide (nmol/l)

$-$

$-$

100

\section{Insulin (nmol/l)}

100

Fig. 8 (A-D). Effect of C-peptide on phosphotyrosine-protein-associated PI 3-kinase activity in 3T3-L1 adipocytes. 3T3L1 fibroblasts were differentiated into adipocytes. Following serum deprivation, the cells were incubated with $100 \mathrm{nmol} / \mathrm{l}$ of insulin, C-peptide, or EGF for $10 \mathrm{~min}$ at $37^{\circ} \mathrm{C}(\mathbf{A})$, with various concentrations of C-peptide $(1,10,100 \mathrm{nmol} / \mathrm{l})$ in the presence or absence of $20 \mathrm{nmol} / \mathrm{l}$ wortmannin, WT $(\mathbf{B})$, or with 100 $\mathrm{nmol} / \mathrm{l}$ of insulin or C-peptide (panel $\mathbf{C}$ ). PI3 K activity was determined in the anti-phosphotyrosine immunoprecipitates as described in Methods. Autoradiographs of TLC plates of representative experiments (out of three with similar results) are shown. Quantitation of data from $\mathbf{C}$ is shown in $\mathbf{D}$ (two experiments in duplicates). $* * * p<0.001, * * p<0.01$ vs control

sulin (10 and $100 \mathrm{nmol} / \mathrm{l})$, corresponding to the submaximal and maximal effective doses, respectively, as determined in the glycogen synthesis and amino acid uptake experiments (Fig. 1 and 2). Cell lysates were immunoprecipitated with anti-IRS-1 antibody and the resulting immunocomplexes were subjected to immunoblotting with anti-phosphotyrosine antibody. No tyrosine phosphorylation of IRS-1 was detected in control cells whereas insulin stimulated tyrosine phosphorylation of IRS-1 fivefold to sixfold (Fig. 9). Cpeptide at both 0.3 and $3 \mathrm{nmol} / \mathrm{l}$ also significantly increased tyrosine phosphorylation of IRS-1 (by 50 and $180 \%$, respectively) suggesting that activation of IRS-1 is involved in C-peptide signalling pathway. 
A

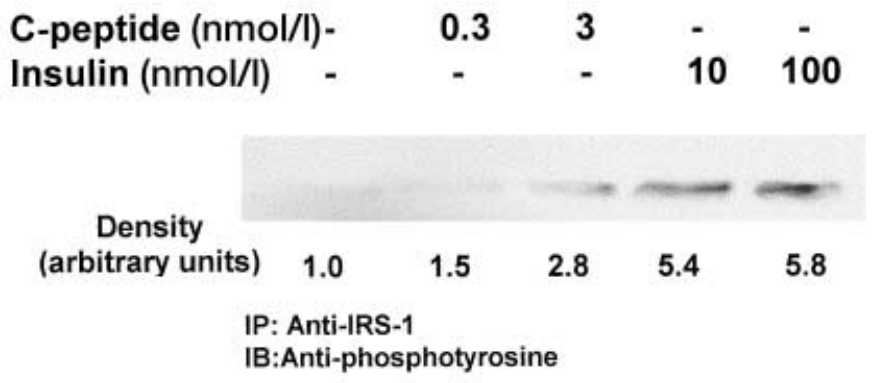

B

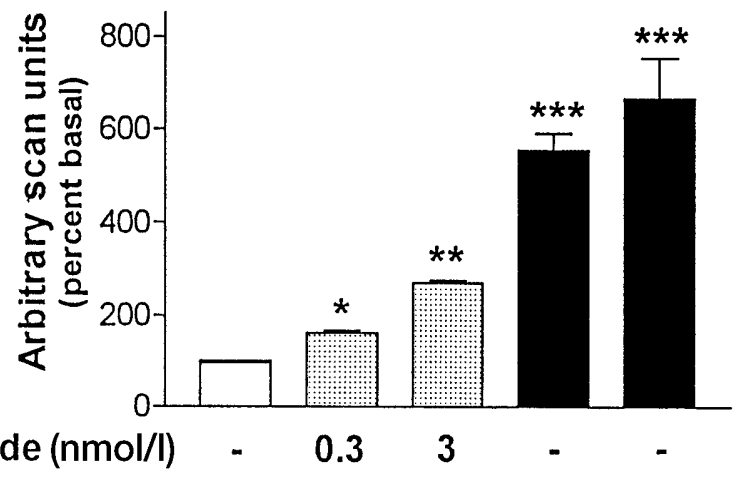

C-peptide (nmol/)

Insulin (nmol/l) - $\quad$ - $\quad$ - 10100

Fig. 9 (A, B). Effect of C-peptide on IRS-1 phosphorylation. Serum-starved confluent L6 myoblasts were treated with Cpeptide $(0.3,3 \mathrm{nmol} / \mathrm{l})$ or insulin $(10,100 \mathrm{nmol} / \mathrm{l})$. The cell lysates were immunoprecipitated with anti-IRS-1 antibody and subjected to immunoblot analysis using anti-phosphotyrosine antibody. The phosphorylated IRS-1 appears as a band of about $165 \mathrm{kD}$. Arbitrary density units (control =1.0) are indicated for each condition (A). Quantitation of data (three separate experiments) is shown as Means \pm SEM for each condition normalized for control $(=100 \%) * * * p<0.001$, $* * p<0.01, * p<0.05$ vs control (B)

Effect of C-peptide on receptor tyrosine kinase. Binding to the receptor and activation of the insulin receptor tyrosine kinase activity (IR-TKA) initiate the bioeffects of insulin. Because C-peptide increased glycogen synthesis and amino acid uptake in insulin-responsive cells, we tested the ability of C-peptide to stimulate TKA in solubilised, wheat germ agglutinin-purified extracts from L6 myocyte membranes. Insulin, as expected, stimulated TKA $2.2-(10 \mathrm{nmol} / \mathrm{l})$ to 4.5 -fold (100 nmol/1) (Fig. 10A). C-peptide by itself also increased TKA of the extracts in a dose-dependent manner. The bell-shaped concentration response, with maximum effects occurring between 1 and $10 \mathrm{nmol} / \mathrm{l}$, is depicted in Figure $10 \mathrm{~A}$. The 1.8fold-2.6-fold, statistically significant increase in TKA caused by C-peptide, was similar to the one stimulated by $10 \mathrm{nmol} / \mathrm{l}$ insulin. Concentrations of Cpeptide leading to the maximum TKA were thus in the range seen physiologically and in our glycogen synthesis and amino acid uptake experiments (Figs. 1 and 2). Scrambled C-peptide sequence by itself had no effect on TKA (experiments with $3 \mathrm{nmol} / \mathrm{l}$ shown in Fig. 10A). Scrambled C-peptide on its own or with insulin, with C-peptide, or with a combination of insulin and C-peptide had no effect on TKA (not shown). When compared with submaximally effective insulin $(10 \mathrm{nmol} / \mathrm{l})$ concentration, the combination of insulin and C-peptide increased TKA of the L6 myoblast membrane extracts over that of either ligand alone (Fig. 10B). These results suggest that the insulinomimetic effects of C-peptide in L6 cells could be initiated by activation of TKA. To determine whether IR contributes to the TKA stimulation in these experiments by C-peptide, we used immunoprecipitated IRs (from the WGA-purified membrane preparation using an antibody against IR- $\alpha$-subunit) in an in vitro kinase assay. As expected, insulin stimulated IR-TKA (Fig. 10C). C-peptide ( 0.3 and $3 \mathrm{nmol} / \mathrm{l})$ exerted a twofold stimulation of IR-TKA. Combination of submaximal insulin $(10 \mathrm{nmol} / \mathrm{l})$ and C-peptide $(0.3 \mathrm{nmol} / \mathrm{l})$ concentrations increased IR-TKA to the same degree as either ligand alone scrambled C-peptide had again no effect (Fig. 10C).

Effect of C-peptide on insulin receptor autophosphorylation. In our experiments C-peptide increased autophosphorylation of IR in HIRcB cells [14]. We extended this earlier observation to the more physiologically relevant L6 myoblasts. C-peptide (0.3 and 3 $\mathrm{nmol} / \mathrm{l}$ ) increased IR phosphorylation on tyrosine residues threefold to fourfold (Fig. 11), an effect of C-peptide which was considerably weaker than that of insulin concentrations used in the assays testing the more distal elements of insulin signalling $(10,100$ $\mathrm{nmol} / \mathrm{l})$. These data suggest that the C-peptide-induced TKA (Fig.10) could at least partly be due to IR present in the L6 membrane preparations. There was no increase in the tyrosine phosphorylation of the receptor's $\beta$-subunit when scrambled C-peptide was used (not shown). We did not find any significant additivity of insulin and C-peptide on tyrosine phosphorylation of IR.

Effect of pertussis toxin on C-peptide stimulated glycogen synthesis. Because the putative specific C-peptide receptor might be pertussis toxin-sensitive, Gprotein-coupled [8], we used pertussis toxin to determine its effect on C-peptide stimulated glycogen synthesis. Wortmannin inhibited both insulin- and Cpeptide glycogen synthesis but no effect was seen with pertussis toxin in L6 myoblasts (Fig. 7).

\section{Discussion}

This study shows that C-peptide, at physiological concentrations, mimics insulin effects such as glycogen synthesis and amino acid uptake in rat muscle cells. Addressing the specificity of the C-peptide effects, 


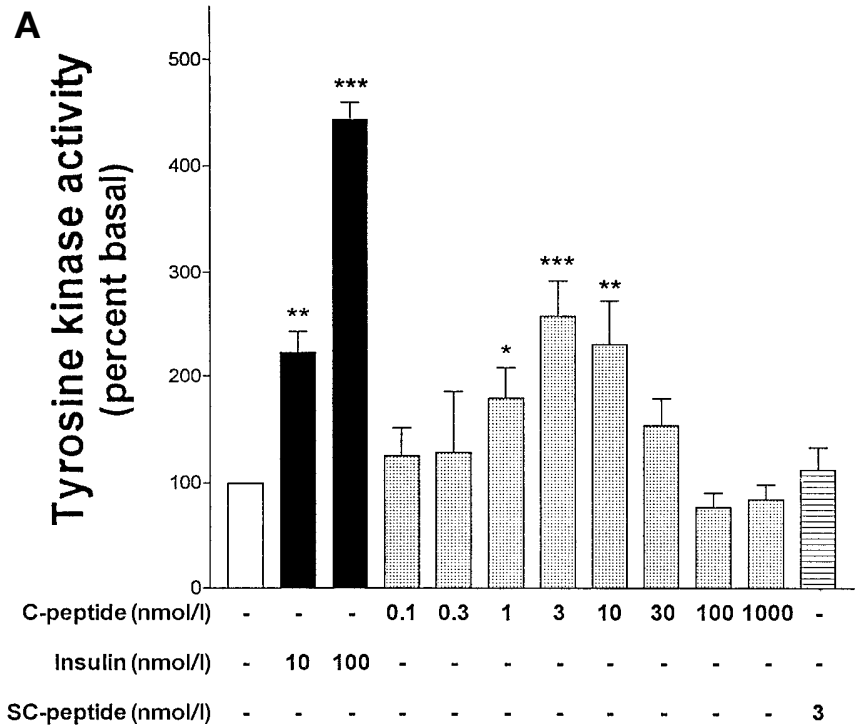

B

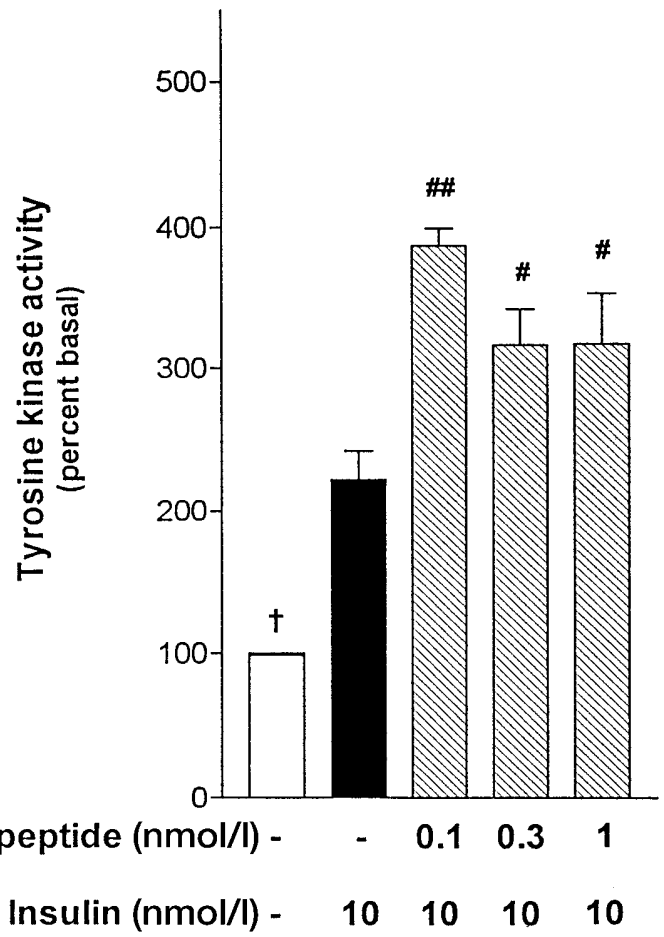

C

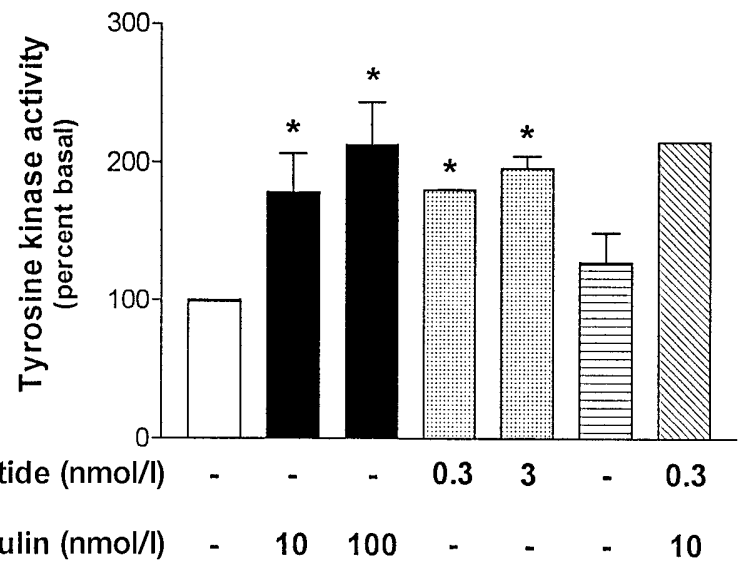

SC-peptide (nmol/l) we show that a scrambled C-peptide sequence does not have any of the insulin-like effects of the native molecule. C-peptide also stimulates 3-O-methylglucose transport in human skeletal muscle strips [9, 10]. To identify the mechanism for C-peptide signal transduction, we investigated the effects of C-peptide in an insulin-sensitive system, focusing on intermediaries of the known insulin signalling pathways. Insulin signalling is initiated by insulin binding to IR, followed by receptor autophosphorylation and activation of IR-TKA, resulting in tyrosine phosphorylation of several cytosolic substrates, such as the IRS proteins $[12,13]$. Subsequently, activation of PI3 K plays a central role in regulating glucose transport and glycogen synthesis. We first confirmed that insulin (10-100 nmol/l) activated IR autophosphorylation and TKA as well as several elements of its signal transduction pathway, culminating in increased glycogen synthesis and amino acid uptake in L6 myoblasts and myotubes. C-peptide, at physiological concentrations (generally between 0.3 and $3 \mathrm{nmol} / \mathrm{l}$ in our assays), mimics qualitatively the effects of insulin. An exception was Akt (protein kinase B), where Cpeptide had no effect according to three different methods in L6 cells. Akt is believed to be necessary for the insulin-induced activation of glycogen synthesis in L6 myotubes [24]. Stimulation of glycogen synthase by insulin is mediated by dephosphorylation through the activation of PP1G and inhibition of GSK3, which, in turn, is inhibited by phosphorylation. There are at least three plausible kinases which could phosphorylate GSK3 or PP1G: p70S6 kinase, p90Rsk and Akt. Our data suggest that C-peptide stimulates glycogen synthesis without activating Akt. Whether this response is mediated by a p70S6k-dependent or p90Rsk-dependent or both [25] and Aktindependent pathway(s) is being investigated. Because of the presence of additional mechanisms (e.g. stimulation of PPG1) for regulation of glycogen synthesis only qualitative comparisons can be drawn between our data on C-peptide effect on glycogen synthesis and GSK3 phosphorylation.

Fig. 10 (A-C). C-peptide activates tyrosine kinase in L6 myotubes. Receptors partially purified from L6 plasma membranes were incubated with insulin, C-peptide, scrambled C-peptide (A) or combination of insulin and C-peptide (B). TKA of receptors was assayed by phosphorylation of the synthetic substrate poly $\left(\mathrm{Glu}^{4} \mathrm{Tyr}^{1}\right)$ in the presence of $\left[\gamma_{-}{ }^{32} \mathrm{P}\right]$-ATP. In separate experiments, cell lysates were immunoprecipitated with anti-IR antibody and immunocomplexes were captured with protein G/protein A-agarose. TKA of this preparation was assayed as described above $(\mathbf{C})$. Results are shown as Means \pm SEM of three separate experiments (each in quadruplicate) and normalized with respect to control $(=100 \%)$. $* * * p<0.001, * * p<0.01, * p<0.05$ vs control $(\mathbf{A}, \mathbf{C}) ;{ }^{\dagger} p<0.05$ vs every sample, $\# p<0.05, \# \# p<0.01$ vs insulin, $10 \mathrm{nmol} / \mathrm{l}(\mathbf{B})$ 


\section{C-peptide (nmol/l) - Insulin (nmol/l) -}

\section{3}

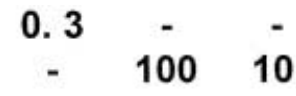

Density

(arbitrary units)
1.0
3.9

3.1
14.2

7.0
IP: Anti-insulin receptor ß-subunit IB: Anti-phosphotyrosine

Fig. 11. Effect of C-peptide on autophosphorylation of the L6 insulin receptor. Serum-deprived confluent L6 myoblasts were incubated with C-peptide $(0.3,3 \mathrm{nmol} / \mathrm{l})$ or with insulin $(10,100 \mathrm{nmol} / \mathrm{l})$. Cell lysates were immunoprecipitated with anti-IR $\beta$-subunit antibody and then immunoblotted using anti-phosphotyrosine antibody. The phosphorylated IR $\beta$-subunit is shown as a band of about $95 \mathrm{kD}$ in the representative autoradiograph. Arbitrary density units (control =1.0) are indicated for each condition

Even though the cellular and tissue effects of Cpeptide and its beneficial effects in Type I diabetic patients and in animal models have been reported, the molecular underpinnings for these observations are not known [3-6]. There are at least four distinct possibilities for explaining our data. Firstly, C-peptide effects could result from direct binding to, and activation of, a specific C-peptide receptor. Although the presence of such a receptor has not been unequivocally proven, a putative receptor has been found $[2$, 8]. Investigations suggest that the $\mathrm{C}$-peptide receptor is a surface entity probably coupled to its signal transduction pathway by a $\mathrm{G}$ protein. The latter hypothesis is based on the blunted C-peptide effects by pertussis toxin. We cannot rule out this possibility even though our preliminary data do not indicate any effect of pertussis toxin on C-peptide-stimulated glycogen synthesis in L6 myoblasts.

The second possibility for explaining our data is that C-peptide activates the IR. The lack of C-peptide stimulation of glycogen synthesis in the parental rat 1 fibroblasts (which contain few IR) but robust effects in HIRcB (overexpressing human IR, not shown) cells suggest a role of IR in mediating the C-peptide effect. Given the structural differences between insulin and C-peptide, interaction with IR would need to occur with an $\alpha$-subunit domain distinct from that responsible for insulin binding to IR. Alternatively, a plasma membrane perturbation caused by C-peptide could lead indirectly to a conformational change of the IR leading to activation of its $\beta$-subunit i.e. its autophosphorylation and activation of TK. The fact that only submaximal concentrations of both C-peptide and insulin are additive suggests that at least some elements of the signalling pathways used by these ligands are shared. Interestingly, in smooth muscle arterioles the effect of C-peptide on arteriolar dilation was potentiated in the presence of low insulin concentrations alone [26]. They concluded that the C-peptide interac- tion with insulin is biologically important and concentration dependent. This interaction might be missing in patients treated solely with insulin replacement.

The third possibility for explaining our data is a combination of the two above explanations: interaction of C-peptide with its cognate membrane receptor and with a specific domain of the IR. A fourth explanation is an interaction of C-peptide with another cell surface receptor such as the IGF-1 receptor. Both IGF-1 and C-peptide share structural domains, which could form the basis for cross talk between their signalling pathways. We have already shown that C-peptide replacement normalizes both IGF and IGF-1 receptor expression [6,27].

To recapitulate the arguments of the long-standing controversy about the very presence of a specific Cpeptide receptor is beyond the scope of this paper [2, 8]. Specific C-peptide binding by the conventional radioimmunoassay has not been shown. The introduction of the sensitive FCS technique allowed specific C-peptide binding to human cells to be shown [8]. The low receptor density made the use of the relatively crude radioligand assays difficult, a situation which can be compared with that of the galanin receptor. Overexpression of the galanin receptor made it possible to show high-affinity binding sites by a conventional method in addition to the use of FCS [28].

A lack of TK stimulation by C-peptide in muscle strips from healthy and diabetic subjects has been reported [10]. C-peptide did, however, increase glucose transport into those muscle strips [9]. It is not clear whether tissue or species or technical differences account for the difference of our observations.

When we look at the respective insulin and C-peptide concentration response curves, we should remember that $10 \mathrm{nmol} / \mathrm{l}$ insulin is typically necessary to document statistically significant responses in in vitro systems. Higher insulin concentrations increase the effect, with 100-1000 nmol/l resulting in the maximal stimulation of a response tested in the various assays. In contrast, considerably less C-peptide, on a molar basis, is sufficient to elicit insulin-like responses, even though these are less robust quantitatively than those seen with insulin alone. Peaks of C-peptide responses are reached at about $0.3-3 \mathrm{nmol} / \mathrm{l}$. Interestingly, half saturation of the putative C-peptide receptor occurs at $0.3 \mathrm{nmol} / \mathrm{l}$ and full saturation at 0.9 $\mathrm{nmol} / \mathrm{l}$ of the peptide [8], i.e. concentrations found fully effective in the L6 cell system used in the present report. In contrast to insulin, higher doses of C-peptide ( $>10 \mathrm{nmol} / \mathrm{l}$ ) blunt the stimulatory responses. Any extrapolation of these observations into mammalian physiology is, of course, premature but the addition of low C-peptide and low insulin concentrations could be advantageous for fuel storage. Conversely, in the postprandial situation, in the presence of exuberant insulin release, the concomitant higher C-peptide levels could blunt insulin's peripheral effects. 
In summary, in insulin-sensitive rat L6 myoblasts (as well as in differentiated myocytes), C-peptide in physiological amounts mimics several of insulin's bioeffects. Signal transduction pathways tested here are activated by C-peptide alone and are similar to those used by insulin with exception of Akt phosphorylation. Once the C-peptide receptor is cloned and sequenced, details of the molecular interaction between the insulin and C-peptide signalling pathways will be clearer.

Acknowledgements. We gratefully acknowledge the gift of rat and human C-peptide and scrambled C-peptide from Dr. J. Wahren (Karolinska Institutet, Sweden, Stockholm). The study was supported in part by grants to (Z. Li, A. Sima) and postdoctoral fellowships (X. Qiang., S.T. Mathews) from the Wayne State University Morris J. Hood, Jr. Comprehensive Diabetes Center and from the Henry L. Brasza Endowment (G. Grunberger).

\section{References}

1. Rubenstein A, Clark J, Melani F, Steiner D (1969) Secretion of proinsulin C-peptide by pancreatic beta cells and its circulation in blood. Nature (London) 224: 697-699

2. Wahren J, Ekberg K, Johansson J et al. (2000) Role of Cpeptide in human physiology. Am J Physiol Endocrinol Metab 278:E759-E768

3. Wahren J, Johansson B-L, Wallberg-Henriksson H (1994) Does C-peptide have a physiological role? Diabetologia 37 [Suppl 2]: S99-S107

4. Johansson B-L, Kernell A, Sjöberg S, Wahren J (1993) Influence of combined C-peptide and insulin administration on renal function and metabolic control in diabetes type 1. J Clin Endocrinol Metab 77: 976-981

5. Johansson B-L, Borg K, Fernqvist-Forbes E, Odergren T, Remahl S, Wahren J (1996) C-peptide improves autonomic nerve function in IDDM patients. Diabetologia 39: 687-695

6. Sima AAF, Zhang W, Sugimoto K et al (2001) C-peptide prevents and improves chronic type 1 diabetic polyneuropathy in the $\mathrm{BB} /$ Wor rat. Diabetologia

7. Ido Y, Vindigni A, Chang K et al. (1997) Prevention of vascular and neural dysfunction in diabetic rats by $\mathrm{C}$-peptide. Science 277: 563-566

8. Rigler R, Pramanik A, Jonasson P et al. (1999) Specific binding of proinsulin C-peptide to human cell membranes. Proc Natl Acad Sci USA 96: 13318-13323

9. Zierath J, Galuska D, Johansson B-L, Wallberg-Henriksson H (1991) Effect of human C-peptide on glucose transport in vitro incubated human muscle. Diabetologia 34: 899-901

10. Zierath JR, Handberg A, Tally M, Wallberg-Henriksson H (1996) C-peptide stimulates glucose transport in isolated human skeletal muscle independent of insulin receptor and tyrosine kinase activation. Diabetologia 39: 306-313

11. Cheatham B, Kahn CR (1995) Insulin action and the insulin signaling network. Endocr Rev 16: 117-142
12. Holman GD, Kasuga M (1997) From receptor to transporter: insulin signaling to glucose transport. Diabetologia 40: 991-1003

13. Virkamäki A, Ueki K, Kahn CR (1999) Protein-protein interaction in insulin signaling and the molecular mechanisms of insulin resistance. J Clin Invest 103: 931-943

14. Sima AAF, Srinivas PR, Kommaraju S, Verma S, Grunberger G (1998) Enhancement of insulin receptor activity by C-peptide. Diabetologia 41 [Suppl 1]: A177 (Abstract)

15. Clancy BM, Czech MP (1990) Hexose transport stimulation and membrane redistribution of glucose transporter isoforms in response to cholera toxin, dibutyryl cyclic AMP, and insulin in 3T3-L1 adipocytes. J Biol Chem 265: 12434-12443

16. Zick Y, Grunberger G, Rees-Jones RW, Comi RJ (1985) Use of tyrosine-containing polymers to characterize the substrate specificity of insulin and other hormone-stimulated tyrosine kinases. Eur J Biochem 148: 177-182

17. Halse R, Rochford JJ, McCormack JG, Vandenheede JR, Hemmings BA, Yeaman SJ (1999) Control of glycogen synthesis in cultured human muscle cells. J Biol Chem 274: 776-780

18. Su T-Z, Wang M, Syu L-J, Saltiel AR, Oxender DL (1998) Regulation of amino acid transport in 3T3-L1 adipocytes by insulin. J Biol Chem 243: 3173-3179

19. Sbrissa D, Ikonomov OC, Shisheva A (1999) PIKfyve, a mammalian ortholog of yeast Fab1 p lipid kinase, synthesizes 5-phosphoinositides. J Biol Chem 274: 21589-21597

20. Mathews ST, Chellam N, Srinivas PR et al. (2000) $\alpha_{2}-\mathrm{HSG}$, a specific inhibitor of insulin receptor autophosphorylation, interacts with the insulin receptor. Mol Cell Endocrinol 164: 87-98

21. Ogihara T, Shin B-C, Anai M et al. (1997) Insulin receptor substrate IRS-2 is dephosphorylated more rapidly than IRS-1 via association with phosphatidylinositol 3-kinase in skeletal muscle cells. J Biol Chem 272: 12868-12873

22. Jensen CJ, Buch M-B, Krag TO, Hemmings BA, Gammeltoft S, Frodin M (1999) $90-\mathrm{kDa}$ ribosomal S6 kinase is phosphorylated and activated by 3-phosphoinositide-dependent protein kinase-1. J Biol Chem 274: 27168-27176

23. Fruman DA, Meyers RE, Cantley LC (1998) Phosphoinositide kinases. Annu Rev Biochem 67: 481-507

24. Takata M, Ogawa W, Kitamura T et al. (1999) Requirement for Akt (protein kinase B) in insulin-induced activation of glycogen synthase and phosphorylation of 4E-BP1 (PHAS-1). J Biol Chem 274: 20611-20618

25. Shepherd PR, Nave BT, Siddle K (1995) Insulin stimulation of glycogen synthesis and glycogen synthase activity is blocked by wortmannin and rapamycin in 3T3-L1 adipocytes: evidence for the involvement of phosphoinositide 3kinase and p70 ribosomal protein-S6 kinase. Biochem J 305: $25-28$

26. Jensen ME, Messina EJ (1999) C-peptide induces a concentration-dependent dilation of skeletal muscle arterioles only in presence of insulin. Am J Physiol 276:H1223-H1228

27. Li Z, Zhang W, Grunberger G, Sima AAF (2000) C-peptide corrects IGF's and prevents apoptosis in type $1 \mathrm{BB} /$ Wor-rat hippocampus. Diabetes 49 [Suppl 1]: A229

28. Kask K, Berthold M, Kahl U, Nordvall G, Bartfai T (1996) Delineation of the peptide binding site of the human galanin receptor. EMBO J 15: 236-244 